\title{
Two new records for the Lamiaceae of Singapore
}

\author{
R.P.J. de Kok ${ }^{1}$, S. Sengun ${ }^{2,3}$ \& G.L.C. Bramley ${ }^{3}$ \\ ${ }^{1}$ Honorary Research Associate, Singapore Botanic Gardens, \\ National Parks Board, 1 Cluny Road, Singapore 259569 \\ dekokrogier@gmail.com \\ ${ }^{2}$ Birkbeck, University of London, Malet St, London WC1E 7HX, U.K. \\ ${ }^{3}$ Royal Botanic Gardens Kew, Richmond, Surrey TW9 3AE, U.K.
}

\begin{abstract}
The species of Lamiaceae have recently been revised for Singapore. In total 44 species in 21 genera are recorded, of which 23 species are native, an additional five are probably native, and 16 are non-native species which have naturalised in Singapore. One new record for Singapore has been found (Vitex rotundifolia) and one species reinstated (Callicarpa pentandra) after being ignored for over a hundred years.
\end{abstract}

Keywords. Callicarpa pentandra, conservation, distributions, Vitex rotundifolia

\section{Introduction}

The Lamiaceae (Mint Family) is of major ecological and economic importance in Southeast Asia. It includes major (Gmelina L. \& Tectona L.f.) and minor (Teijsmanniodendron Koord. and Vitex L.) timber groups. It is important horticulturally (Clerodendrum L. and its close relatives), culinarily (Mentha L. and Ocimum L.) and medicinally (Vitex). As a consequence, members of the family are often cultivated and have been moved around the region, in some case over many centuries. Taxonomically the family is complex with many species-rich genera, some of which have undergone major nomenclatural changes in the last 10 years (De Kok, 2007, 2008, 2012, 2013; Bramley, 2009; De Kok et al., 2009; Wearn \& Mabberley, 2011). Worldwide, the family consists of around 236 genera and about 7200 species (Harley et al., 2004), while in the Flora Malesiana region 50 genera with 302 species are recorded (Bramley et al., in press). In the latest checklist for Singapore, 71 species in 29 genera were recorded (Chong et al., 2009) but this included 25 species and 12 genera known only in cultivation. Since then a number of genera have been revised and, as a consequence, many names have been reduced into synonymy and a few new species have been recognised. In addition, a number of genera have been investigated using molecular phylogenetic techniques, which has led to some genera being lumped together (e.g. Bramley et al., 2009), while others have been split (e.g. Yuan et al., 2010).

One of the key problems in this study has been how to determine if a species is native or naturalised in Singapore. Thanks to the taxonomic work done by several authors in the last 10 years on a series of genera, our understanding of the distribution of Lamiaceae taxa throughout Southeast Asia is much improved. This has resulted in 
a change in opinion on a whether a number of species are native or introduced. A clear example of this is Gmelina asiatica L., which was thought to be native in Singapore (Chong et al., 2009), but is now considered to be native to India, Thailand and Southern China, but cultivated and naturalised throughout the Southeast Asian region (De Kok, 2012). However, it is clear from looking at herbarium specimens and the available literature, that for some species this cannot always be satisfactorily established. For instance, some species of Clerodendrum and Ocimum have been moved around so much in the past that it is often impossible now to determine their original native distribution (see Bramley et al., in press).

The combination of recent taxonomic and systematic studies has established that there are 44 species in 21 genera in Singapore. Of these, 23 species are native, an additional five are probably native, and 16 are non-native species which have naturalised. These will be enumerated in the forthcoming Flora of Singapore account (De Kok \& Bramley, submitted).

\section{Changes to the species list}

The number of species now recognised as growing in Singapore has decreased. This can be attributed in part to a reduction in species to synonymy (see Bramley et al., in press). A good example is the genus Premna L., where three names (Premna corymbosa Rottler \& Willd., P. foetida Reinw. ex Blume and P. punctulata C.B.Clarke) have been placed in the synonymy of $P$. serratifolia L. (De Kok, 2013). In addition, only one name has been added to the list due to a species being split. This is the recognition of Ocimum x africanum Lour. as distinct after previously being placed in synonymy of Ocimum americanum L. (Suddee et al., 2005).

The number of genera has also changed. For instance, both Hyptis Jacq. and Clerodendrum L. have been split into several distinct genera: Hyptis is now recognised as three genera in Malesia (Hyptis, Cantinoa Harley \& Pastore and Mesosphaerum P.Browne - see Harley \& Pastore, 2012), and Clerodendrum also as three genera in Malesia (Clerodendrum, Rotheca Raf. and Volkameria L. - see Yuan et al., 2010).

Only two species have been added to the Singapore checklist. Callicarpa pentandra Roxb. was previously recorded by Ridley in 1900 since when it has been entirely omitted from any mention in the Singapore flora. We, therefore, treat it here as effectively a new record. Vitex rotundifolia L.f. has never previously been recorded for Singapore.

\section{Conservation}

In the last 200 years Singapore has lost $99.8 \%$ of its primary forests and this deforestation has had a particularly bad impact on its coastal habitats (39\% species loss), but a lesser impact on inland forests ( $29 \%$ species loss) and open vegetation (5\% species loss) (Turner et al., 1994). In terms of life forms, over the same period, $19 \%$ of trees, $34 \%$ 
of shrubs, $17 \%$ of herbs, $23 \%$ of climbers and $62 \%$ of epiphytic species have been lost (Turner et al., 1994). In the Lamiaceae, $33 \%$ of coastal species, $45 \%$ of inland species and $25 \%$ of open vegetation species are presumed extinct. This translates into the loss of $28 \%$ of its trees, $57 \%$ of its shrubs, and all of its true climbers. However, all of its herbs have survived.

In Chong et al.'s 2009 checklist, all native species were given a national IUCN conservation assessment, while those deemed non-native were designated as cultivated, casual or naturalised (Chong et al., 2009). In our study native species as accepted in the Flora of Singapore (De Kok \& Bramley, submitted) and not accounted for in Chong et al. (2009) are given a national IUCN conservation assessment.

From Table 1 it is clear that in general, the numbers of nationally extinct and Critically Endangered species have decreased, while the number of species of least concern has increased. This is mainly due to the fact that some of the presumed extinct species in Chong et al. (2009) have now been placed in synonymy of more common species. Also, some species which were previously thought to be introduced have now been reclassified as native and Least Concern.

Table. 1. Difference in the number of native species for each category in national IUCN conservation assessments between the 2009 checklist (Chong et al., 2009) and the as-yet unpublished Flora of Singapore account (De Kok \& Bramley, submitted). LC = Least Concern; $\mathrm{VU}=$ Vulnerable; $\mathrm{EN}=$ Endangered $; \mathrm{CR}=$ Critically Endangered; $\mathrm{EX}=$ Extinct.

\begin{tabular}{lcc}
\hline Local IUCN assessments & $\begin{array}{c}\text { Chong et al., } \\
2009\end{array}$ & De Kok \& Bramley, submitted \\
\hline Least Concern (LC) & 5 & 7 \\
Vulnerable (VU) & 3 & 2 \\
Endangered (EN) & 2 & 3 \\
Critically Endangered (CR) & 4 & 3 \\
Extinct (EX) & 9 & 7 \\
\hline
\end{tabular}

\section{New Records for Singapore}

Callicarpa pentandra Roxb., Fl. Ind. 1: 409 (1820); Moldenke, Phytologia 50: 365 (1982); Bramley, Bot. J. Linn. Soc. 159: 443 (2009). - Geunsia pentandra (Roxb.) Merr., Philipp. J. Sci. C11: 309 (1916). - TYPE: Indonesia, Moluccas, collector uncertain (lectotype G-DC [G00312486], designated in Bramley (2013)). (Fig. 1)

Geunsia farinosa Blume, Cat. Gew. Buitenzorg 12 (1823); Ridl., Fl. Singapore 96 (1900). - Callicarpa pentandra Roxb. forma farinosa (Blume) Bakh., Bull. Jard. Bot. Buitenzorg, sér. III, 3: 13 (1921). - TYPE: Indonesia, Blume s.n. (holotype L). 
Geunsia farinosa Blume var. callicarpoides H.J.Lam ex Moldenke, Phytologia 50: 220 (1982). - TYPE: Indonesia, Kalimantan, collector unknown (holotype L).

Callicarpa cumingiana Schauer in A.DC., Prodr. 11: 644 (1847). - Geunsia cumingiana (Schauer) Rolfe, Journ. Linn. Soc., Bot. 21: 315 (1884). - Callicarpa pentandra var. cumingiana (Schauer) Bakh., Bull. Jard. Bot. Buitenzorg, sér. III, 3: 16 (1921). - TYPE: Philippines, Cuming 1707 (lectotype K, designated in Bramley (2013); isolectotype P).

Callicarpa hexandra Teijsm. \& Binn., Cat. Hort. Bot. Bogor 410 (1863). - Geunsia hexandra (Teijsm. \& Binn.) Koord., Meded. Lands Plantentuin 19: 559 (1898). Callicarpa pentandra Roxb. forma hexandra (Teijsm. \& Binn.) Bakh., Bull. Jard. Bot. Buitenzorg, sér. III, 3: 13 (1921). - TYPE: Celebes [Sulawesi], Menado, Minahassae, de Vriese \& Teijsmann s.n., (lectotype L, designated in Bramley (2013)).

Geunsia hexandra (Teijsm. \& Binn.) Koord. var. macrophylla Moldenke, Phytologia 49: 430 (1981). -TYPE: Malaysia, Sabah, Tawau district, Luasong, 25 February 1979, Fedilis \& Sumbing SAN89702 (holotype SAN; isotype K).

Callicarpa affinis Elmer, Leafl. Philipp. Bot. 3: 864 (1910). - TYPE: Philippines, Mindanao, Davao district, Todaya (Mt Apo), June 1909, Elmer 11102 (lectotype K, designated in Bramley (2013); isolectotypes GH, L, L, NY, US).

Callicarpa serrulata (Hallier f.) Govaerts, World Checklist Seed P1. 3(1): 12 (1999). - Geunsia serrulata Hallier f., Meded. Rijks-Herb. 37: 27 (1918). - TYPE: Borneo, Gebiet des Sambasstromes, 30 October 1893, Hallier 801 (holotype L; isotypes BO x3).

Geunsia serrulata forma anisophylla (Hallier f.) Moldenke, Phytologia 50: 378 (1982). - Geunsia anisophylla Hallier f., Meded. Rijks-Herb. 37: 29 (1918). - TYPE: Borneo, Müllergebirge, 14 March 1894, Hallier B2741 (holotype L; isotypes BO x3).

Callicarpa subternata (Hallier f.) Govaerts, World Checklist Seed Pl. 3(1): 12 (1999). - Geunsia subternata Hallier f., Meded. Rijks-Herb. 37: 25 (1918). - TYPE: Borneo, Sungei Tikung, November 1912, Amdjah 973 (holotype L; isotype BO).

Geunsia hookeri Merr., Philipp. J. Sci. 7: 342 (1912). - TYPE: Philippines, Cebu, Cuming 1773 (lecto K, designated in Bramley (2013); isolectotypes GH, K, L).

Callicarpa weberi Merr., Philipp. J. Sci. 12: 298 (1917). - TYPE: Philippines, Bancalan Island, 26 September 1916, Weber 68 (lectotype A, designated in Bramley (2013)).

Callicarpa longivillosa Merr., Philipp. J. Sci. 17: 313 (1920). - TYPE: Philippines, Mindanao, Surigao prov., 19 April 1919, Ramos \& Pascasio Bur. Sci. 34538 (lectotype $\mathrm{K}$, designated in Bramley (2013); isolectotypes BM, BO). 

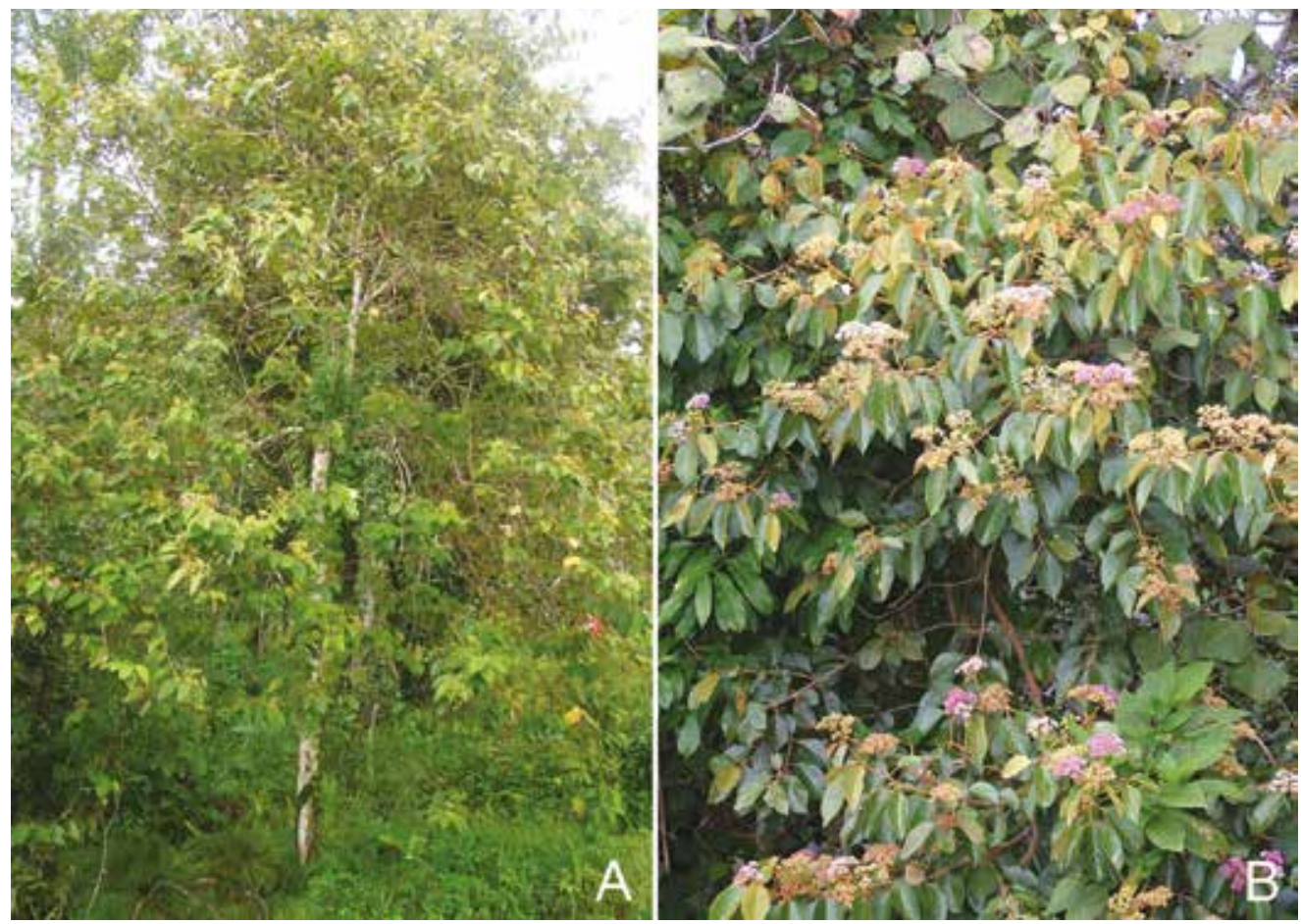

Fig. 1. Callicarpa pentandra Roxb. A. Habit. B. Inflorescences. (Photos: G. Bramley from Lambir, Sarawak)

Callicarpa pentandra Roxb. var. paloensis (Elmer) Bakh. forma furfuracea Bakh., Bull. Jard. Bot. Buitenzorg, sér. III, 3: 15 (1921). - Geunsia furfuracea (Bakh.) Moldenke, Amer. J. Bot. 32: 612 (1945). - TYPE: Indonesia, Celebes [Sulawesi], Kp. Tapalang Mamoedjoe, 4 August 1912, Van Vuuren \& Noerkas 425 (lectotype BO, designated in Bramley (2013); isolectotypes K, L).

Geunsia cumingiana (Schauer) Rolfe var. pentamera H.J.Lam, Verbenaceae Malayan Archipel. 36 (1919). - TYPE: Philippines, Daraga, Com. d.1. Fl. for. no 844 (syntype not found); New Guinea, Hollandia, Gjellerup 416a 416b, 416c (syntypes all BO not found); Stephansort, Nyman 52 (syntype BO not found); Kaiser Wilhelmsland, Weinland s.n. (syntype BO not found).

Callicarpa pentandra var. cumingiana (Schauer) Bakh. forma dentata Bakh., Bull. Jard. Bot. Buitenzorg, sér. III, 3: 17 (1921). - Callicarpa cumingiana var. dentata (Bakh.) Moldenke, Phytologia 5: 8 (1954). - TYPE: Java, Noesa Kembangan, Backer 4611 (lectotype BO, designated in Bramley (2013); isolectotype BO).

Callicarpa ridleyi S.Moore, J. Bot 63 (Suppl.): 80 (1925). - TYPE: Java, Mt Salak, November 1879, Forbes 272 (holotype BM). 
Callicarpa pullei (H.J.Lam) Govaerts, World Checklist Seed Pl. 3: 12 (1999). Geunsia pullei H.J.Lam, Verben. Malay. Archip. 35 (1919). - TYPE: West Papua [West Irian], nr Kloofbivak, Pulle 261 (holotype L; isotypes BO, Z).

Shrub or tree to $20 \mathrm{~m}$, DBH $2-35 \mathrm{~cm}$; outer bark light brown, \pm smooth, inner bark yellowish, fibrous. Young branches/twigs with a dense indumentum of brown plumose or short-branched hairs, often farinose, or longer, patent hairs that appear simple but have numerous short branches at the base, also with yellow sessile glands. Leaves often with apparently alternate leaves between opposite pairs, narrowly elliptic to elliptic to narrowly ovate to almost ovate, $11-29 \times 4-15 \mathrm{~cm}$, margins \pm entire to shallowly dentate, apex markedly to shortly acuminate, base acute to attenuate, rarely almost rounded, truncate or cordate, upper surface variable, either \pm glabrous, or with hairs present along the midvein only, or with simple hairs and hairs that are branched near the base, or farinose, with scattered branched hairs, these present especially when young, lower surface variable, either with an indumentum of short-branched hairs on the venation only (including tertiary), or on the lamina and the venation, forming a raised layer but not obscuring the lamina surface, or with a dense pale coloured indumentum of matted plumose hairs on the lamina, often the individual hairs not visible to the naked eye, in this case the leaves discolorous, in all cases also with yellow sessile glands, occasionally peltate scales present either side of the midrib towards the leaf base; petioles $1.5-3.5 \mathrm{~cm}$, indumentum as twigs. Inflorescence axillary, sometimes appearing terminal, peduncles $40-90 \mathrm{~mm}$ long, indumentum as stem; pedicels $2-2.5$ $\mathrm{mm}$ long, indumentum as stems; bracts and bracteoles inconspicuous, linear, 0.2-10 mm long. Calyx cupular, 1-2 (2.5-3) mm long, \pm truncate or with (4)5(6) shallow triangular lobes, outer surface densely covered with short-branched or \pm plumose hairs, in the latter case the surface obscured, also with yellow sessile glands and occasional peltate scales, inner surface \pm glabrous. Corolla purple, sweetly scented, 4-6 $\mathrm{mm}$ long, divided into (4)5(6) lobes, 1-2 mm long, often reflexed, outer surface with short hairs or papillae and yellow sessile glands, sometimes also with longer branched hairs, inner surface \pm glabrous or papillose, especially on the lobes. Stamens (4)5(6), exserted for 4-5 mm, filaments purple, $5.5-8.5 \mathrm{~mm}$, anthers oblong, pink or purple, $1.5-3 \mathrm{~mm}$ long. Stigma capitate, divided into (4)5(6) small lobes, surface glandular. Fruit green, maturing red, 2-5 mm wide (in dry specimen), slight depression near apex, outer surface glandular, subtended by the calyx, most of which has broken away, sometimes the calyx remaining more intact; (8)10(12) 1-seeded pyrenes.

Distribution. Southern Thailand, Peninsular Malaysia, Sumatra, Borneo, Java, the Philippines, Sulawesi, the Moluccas, New Guinea and possibly the Solomon Islands. In Singapore a native species which has only been recorded twice.

Ecology. In the rest of its range grows mainly in disturbed areas such as roadsides, occasionally found in secondary forest or along margins of primary forest; at 15-1500 $\mathrm{m}$ altitude. 
Provisional Regional IUCN Conservation Assessment. In Singapore believed to be extinct. Globally it is Least Concern (Bramley et al., in press).

Note. Callicarpa pentandra has traditionally been distinguished by its 5-merous flowers; as noted previously (Bramley, 2009), it is not uncommon to find both 4-merous, 5-merous and 6-merous flowers on the same tree. This species was first recorded for Singapore by Ridley (1900), as Geunsia farinosa Blume, but has since been ignored by later authors. For notes on the typification of Callicarpa pentandra refer to Bramley (2013) and discussion of interspecific variation (see Bramley et al., in press).

Callicarpa pentandra is one of the most common species of Callicarpa in Southeast Asia. It is, therefore, surprising that it has only been collected twice in Singapore. The first time was by Nathanial Wallich when he visited the island in 1822 (specimens housed at BM \& K-W), and the second time in 1861 by Thomas Anderson (specimen housed at BM). Interestingly it is the only species of Lamiaceae which is not represented by any Singaporean specimens housed at SING. The presence of this species in Singapore is not surprising given its abundance in the wider region and its ecology. Given that it has not been collected in more than 150 years it is believed to be extinct in Singapore.

Specimens examined. SINGAPORE: Oct 1822, Wallich 1836 (BM, K-W); Oct 1861, Anderson 142 (BM).

Vitex rotundifolia L.f., Suppl. P1. 294 (1782). - TYPE: Japan, Thunberg s.n. (holotype LINN-SM; isotype UPS-THUNB 14619). (Fig. 2)

Vitex ovata Thunb. in Murray, Syst. Veg. 57 (1784); Henderson, Malay. Wild Fl. 1: 387 (1959). - Vitex trifolia var. obovata (Thunb.) Benth., Fl. Austr. 5: 67 (1870), nom. superfl. - Vitex agnus-castus var. ovata (Thunb.) Kuntze, Revis. Gen. P1. 2: 511 (1891). - Vitex trifolia var. ovata (Thunb.) Makino, Bot. Mag. (Tokyo) 17: 92 (1903), nom. superfl. - TYPE: Japan, Thunberg s.n. (holotype UPS-THUNB 14619).

Vitex trifolia var. simplicifolia Cham., Linnaea 7: 107 (1832); De Kok, Kew Bull. 63: 32 (2008). - TYPE: Philippines, Luzon, Cavite, Dec 1817-Jan 1818, Chamisso s.n. (holotype LE).

Vitex repens Blanco, Fl. Filip. 513 (1837); Merrill, Species Blancoanae 332 (1918). - TYPE: Philippines, Luzon, Batangas, Merrill 814 (neotype K [K000182650], designated here by Sengun; isoneotypes L, BM, US, NY).

Vitex trifolia var. ß unifoliolata Schauer in A.P. de Candolle, Prodr. 11: 683 (1847). - TYPE: Japan, Thunberg s.n. (lectotype UPS-THUNB 14619, designated here by Sengun). 
Vitex trifolia var. repens Ridl., Fl. Malay Penin. 2: 631 (1923); Munir, J. Adelaide Bot. Gard. 10: 53 (1987). - TYPE: Malaya, Kelantan, Ridley s.n. (lectotype K, designated here by Sengun; isolectotype SING).

Vitex trifolia subsp. littoralis Steenis, Blumea 8: 516 (1957). - TYPE: [Indonesia] Lesser Sunda Island, Kisar, E of Wonreli, 22 Mar 1939, Bloembergen 3894 (holotype $\mathrm{L}$; isotype BRI).

Prostrate to small erect shrub, 10-60 cm high, sometimes forming dense mats of several metres diameter, rooting at nodes. Leaves 1-foliolate, round to obovate or obovatespatulate, terminal leaflet $1.4-5.3 \times 0.8-3.3 \mathrm{~cm}$, ratio 1.6-1.8, upper surface glabrous or with only few hairs on the veins, lower surface velutinous, hairs whitish, base cuneate, apex mostly rounded, sometimes subacute, margin entire, aromatic when crushed; upper surface green; lower surface pale green to grey-green or silvery; venation 4-7(9) slightly prominent side veins visible on both surfaces; hairs simple, appressed, with powdery wax; petiole 3-12 mm long, round in cross-section; hairs velutinous, white, appressed, simple. Inflorescence terminal and axillary, paniculate, consisting of lateral cymes in dense clusters, 4-12 cm long, angular; hairs dense, appressed, simple. Bracts usually reduced relative to leaves; bracteoles triangular to linear, up to $2 \mathrm{~mm}$ long, appressed, velutinous, usually caducous. Calyx 5-lobed, velutinous, weakly 5-ribbed, slightly accrescent, lobes 2-6 × 3-11 mm; hairs appressed, simple; glands few; flowering calyx 3-4 mm diameter, erect; fruiting calyx $3.5-4.5 \mathrm{~mm}$ diameter, erect, covering most of the mature fruit. Corolla 5-lobed, covered outside with appressed hairs, base glabrous, purplish blue to white; glands many, white; anterior lip 3.9-7 × 3.3-7.4. mm, spatulate, apex rounded to truncate, margin entire, hairs concentrated at base; lateral lobes 3-4.2 × 2-3 mm, reflexed, apex rounded; posterior lip 2-lobed, lobes $3-3.5$ by $3-3.5 \mathrm{~mm}$, reflexed to erect, fused from $10-100 \%$ of total length, apex acute; tube 5.3-8.3 mm long, infundibular. Stamens with filaments 5.2-8.2 mm long, slightly to strongly didynamous, glabrous except for tuft of erect simple multicellular hairs at base, inserted third to half of tube length from corolla base, clearly exceeding the corolla tube; anthers c. 1.5-2 mm long. Style 9.8-14.6 mm long, glabrous; stigma 2-lobed, lobes 6-13 mm long, apex pointed. Ovary 1-1.5 $\mathrm{mm}$ diameter, globose, glabrous, apex covered with glands. Fruit when fresh unknown; dried fruit globose, 4.4-5.3 $\times 4.3-5 \mathrm{~mm}$, glabrous, smooth, turning first purplish, then black when mature. Seeds 4 (or fewer by abortion) per fruit.

Distribution. Widespread from Samoa to the east and north coast of Australia, north to Southern China, Thailand and Japan. The species is apparently absent from most of the central Pacific, but an isolated population occurs in Hawaii. It grows along beaches. In Singapore it is a native species although now believed to be extinct.

Ecology. In the rest of its range grows on sandy seashores, coastal dunes and on sandbars along river. Sometimes grows slightly above the high water mark. 


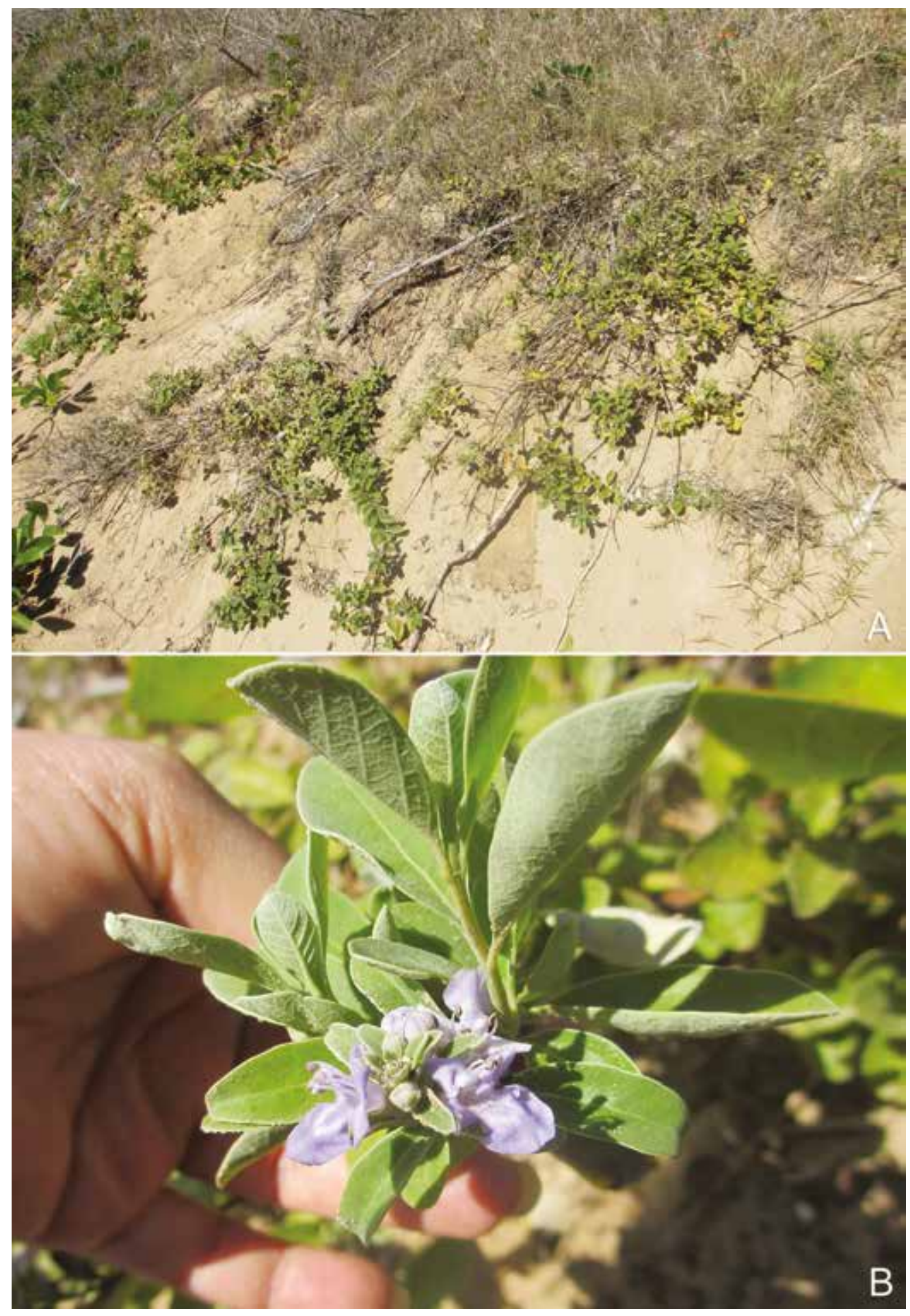

Fig. 2. Vitex rotundifolia L.f. A. Habit. B. Flowers. (Photos: R.P.J. De Kok from Queensland, Australia) 
Provisional Regional IUCN Conservation Assessment. In Singapore it is known only from one collection from 1926 and must now be considered to be extinct. Globally considered to be Least Concern (De Kok, 2007).

Phenology. Flowering and fruiting from June to January.

Notes. Flowers reported to smell like lavender. Otherwise, the whole plant has a pungent smell.

In Singapore this species is only recorded from a single specimen collected by A.W. Hamilton in 1926 which is housed at SING. The collection does not mention any locality details other than 'Singapore'.

This species has often been confused with Vitex trifolia $\mathrm{L}$. and is sometimes treated as a subspecies (De Kok, 2007). Singapore Botanic Gardens was a centre of research on this species complex. Its former Director, Henry Ridley, wrote that Vitex trifolia 'has 2 forms, one a woody sand-creeper with simple round leaves and the other a bush or small tree, growing inland with trifoliate leaves ... plants of the creeping form which I brought from the sand-hills of the east coast of the Malay Peninsula developed into the bush form when cultivated in the Botanic Gardens, Singapore' (Ridley, 1930). However, Corner, not having ever seen any intermediate form between the two, tested this claim by growing 10 plants in the Singapore Botanic Gardens. In the four years these plants were alive, they never became erect shrubs. In addition, he cited upright Vitex trifolia plants that grew on the coastline which did not become creepers; i.e. both plants kept their individual characteristics wherever they grew (Corner, 1939). As a result of an investigation as part of a Ph.D. project (Sengun, in prep.), this taxon is now recognised at the species level.

The coastal vegetation in Singapore has been especially hard hit by development (Turner et al., 1994) and this habitat loss has probably caused the decline of the species in Singapore. Given that it is known only from one collection from 1926 it must be considered nationally extinct.

No type material of Blanco species Vitex repens Blanco could be found. The specimen at K from Merrill's Species Blancoanae series has been selected here as the neotype.

Of the various possible syntypes available for lectotypification of Ridley's taxon Vitex trifolia var. repens, the one collected by himself and housed at $\mathrm{K}$, is selected here as the lectotype.

Of the various syntypes available for lectotypification of the Schauer taxon Vitex trifolia var. B unifiolata, the Thunberg specimen housed at the Uppsala Herbarium was selected here as the lectotype, since it was the only one available for detailed study.

Specimens examined. SINGAPORE: 19 Sep 1926, Hamilton s.n. (SING).

ACKNOWLEDGEMENTS. This research was supported in 2016 by a Singapore Botanic Gardens Research Fellowship to the first author, which is gratefully acknowledged. The first 
author is grateful to Nigel Taylor and David Middleton for all their support. Thanks are due to Bazilah Ibrahim, Serena Lee and many others at the Singapore Botanic Gardens for all their help. We would also like to acknowledge the curators of the BM and $\mathrm{K}$ herbaria for access to the specimens used in this study.

\section{References}

Bramley, G.L.C. (2009). The genus Callicarpa (Lamiaceae) on Borneo. Bot. J. Linn. Soc. 159: 416-455.

Bramley, G.L.C. (2013). The genus Callicarpa (Lamiaceae) in the Philippines. Kew Bull. 68: 369-418.

Bramley, G.L.C., Forest, F. \& De Kok, R.P.J. (2009). Troublesome tropical mints: re-examining generic limits in Lamiaceae subfamily Viticoideae. Taxon 58: 500-510.

Bramley, G.L.C., Bongcheewin, B., Davies, N., Mabberley, D.J., Suddee, S., Walsingham, L.J., Wearn, J.A. \& De Kok, R.P.J. (in press). Lamiaceae. In: Van Welzen (ed) Flora Malesiana, Series I.

Chong, K.Y., Tan, H.T.W \& Corlett, R.T. (2009). A Checklist of the Total Vascular Plant Flora of Singapore, Native, Naturalised and Cultivated Species. Singapore: Raffles Museum of Biodiversity Research, National University of Singapore.

Corner, E.J.H. (1939). Notes on the systematics and distribution of Malayan phanerogams III. Gard. Bull. Straits Settlem. 10: 239-260.

De Kok, R.P.J. (2007). The genus Vitex L. (Labiatae) in New Guinea and the South Pacific Islands. Kew Bull. 62: 587-603.

De Kok, R.P.J. (2008). The genus Vitex (Labiatae) in the Flora Malesiana region, excluding New Guinea. Kew Bull. 63: 17-40.

De Kok, R.P.J. (2012). A revision of the genus Gmelina L. (Lamiaceae). Kew Bull. 67: 293-329.

De Kok, R.P.J. (2013). The genus Premna L. (Lamiaceae) in the Flora Malesiana area. Kew Bull. 68: 55-84.

De Kok, R.P.J., Rusea, G. \& Latiff, A. (2009). The genus Teijsmanniodenron Koord. (Lamiaceae). Kew Bull. 64: 587-625.

Harley, R.M. \& Pastore, J.F.B. (2012). A generic revision and new combinations in the Hyptidinae (Lamiaceae), based on molecular and morphological evidence. Phytotaxa 58: $1-55$.

Harley, R.M., Atkins, S., Budantsev, A.L., Cantino, P.D., Conn, B.J., Grayer, R., Harley, M.M., De Kok, R.P.J., Krestovskaja, T., Morales, R., Paton, A.J., Ryding, O. \& Upson, T. (2004). Labiatae. In: Kubitzki, K. (ed) The Families and Genera of Vascular Plants, Lamiales (except Acanthaceae including Avecenniaceae) VII: 167-275. Berlin: Springer-Verlag.

Ridley, H.N. (1900). The flora of Singapore. J. Straits Branch Roy. Asiat. Soc. 33: 27-196.

Ridley, H.N. (1930). The Dispersal of Plants Throughout the World. Pp. 309-310. London: L. Reeve \& Co. Ltd., Ashford.

Suddee, S., Paton, A. J. \& Parnell, A.J.N. (2005). A taxonomic revision of tribe Ocimeae Dumort. (Lamiaceae) in continental South East Asia. III. Ociminae. Kew Bull. 60: 3-75.

Turner, I.M., Tan, H.T.W, Wee, Y.C., Ali, I., Chew, P.T. \& Corlett, R.T. (1994). A study of plant species extinction in Singapore: Lessons for the conservation of tropical biodiversity. Conservation Biol. 8: 705-712.

Wearn, J.A. \& Mabberley, D.J. (2011). Clerodendrum (Lamiaceae) in Borneo. Syst. Bot. 36: 1050-1061. 
Yuan, Y.-W., Mabberley, D.J., Steane, D.A. \& Olmstead, R.G. (2010). Further disintegration and redefinition of Clerodendrum (Lamiaceae): Implications for the understanding of the evolution of an intriguing breeding strategy. Taxon 59: 125-133. 